\title{
Studies of Human Cord Blood and Adult Lymphocyte Interactions with In Vitro Immunoglobulin Production
}

\author{
T. Morito, A. D. Bankhurst, and R. C. Williams, JR., Department of \\ Medicine, Bernalillo County Medical Center, University of New Mexico \\ School of Medicine, Albuquerque, New Mexico 87131
}

\begin{abstract}
A в S T R A C T Newborns are unable to produce normal amounts of immunoglobulin despite the presence of circulating lymphocytes with surface immunoglobulin (Ig). This study was designed to examine the cellular basis of such impaired Ig synthesis in the newborn infant. An in vitro assay for IgG and IgM synthesis was employed which measured the Ig present in the supernates of pokeweed mitogen-stimulated cord blood and/or adult peripheral mononuclear cells (MNC). Results were as follows: (a) the addition of cord blood MNC to adult MNC suppressed both normal IgG and IgM production; (b) addition of a suspension of adult thymus-derived $(\mathrm{T})$ cells to cord bone marrow-derived (B) cells did not enhance the production of Ig; $(c)$ the addition of cord $T$ cells to adult $B$ cells did not enhance normal Ig production but did significantly depress IgM and IgG synthesis; and $(d)$ irradiation of cord T cells with 2,000 rads removed the suppressive effect of cord $T$ cells on adult MNC. A similar reversal of the suppressive effect exerted by cord MNC was also seen in the presence of $10 \mu \mathrm{M}$ of hydrocortisone. It appears that the inability of newborn infants to make normal amounts of Ig is a result of a combined B-cell defect and the presence of a steroid-sensitive and radiosensitive suppressor cord $\mathrm{T}$ cell.
\end{abstract}

\section{INTRODUCTION}

A number of studies have indicated that the newborn state is associated with a spectrum of abnormalities of immune function. Tolerance of the fetus by the mother without immunological rejection represents the interplay of numerous mechanisms, few of which are as yet clearly understood $(1,2)$. Investigations have been directed at attempts to unravel specific aspects of the maternal-fetal relationship including various types of

Dr. Bankhurst is a Senior Investigator of the Arthritis Foundation.

Received for publication 2 April 1979 and in revised form 29 May 1.97 .9$. blocking factors (3-6) as well as changes in lymphocyte interactions $(7,8)$. One of the most interesting features of the newborn state revolves around the apparent impairment of de novo immunoglobin synthesis in the face of normal proportions and numbers of bone marrow-derived (B) cells with surface immunoglobulin (Ig). Such a situation could theoretically arise from overactive suppressor activity or ineffective thymusderived (T)cell help. A series of observations by Olding et al. $(9,10)$ indicated a suppressive effect of newborn human lymphocytes on division of cocultured maternal T lymphocytes. Additional evidence for active suppression by T-suppressor cells in human cord blood has recently been presented (11). This study was directed at an attempt to answer a number of specific questions: (a) do human cord lymphocytes suppress Ig production of adult human B lymphocytes? (b) are cord B cells capable of being helped by adult helper $T$ cells? and (c) is the human cord suppressor cell sensitive to indomethacin, corticosteroids, or irradiation? This study attempts to examine human $\mathrm{T}$ - and B-cell interactions in cord and adult samples to dissect out features of cellular interaction which might contribute to lowered or depressed immune reactivity during the newborn and early human developmental period.

\section{METHODS}

Preparation of lymphocytes. Peripheral blood mononuclear cells $(\mathrm{MNC})^{\mathbf{1}}$ were separated on Ficoll (Pharmacia Fine Chemicals, Inc., Piscataway, N. J.) -Hypaque (Winthrop Laboratories, New York) gradients (12) and washed three times with Hanks' balanced salt solution (HBSS). Normal adult control samples were obtained from healthy donors of both sexes between the ages of 18 and 45 . Cord blood was obtained from placentas at the time of delivery and placed in heparinized tubes (preservative-free heparin, 1,000 U/10 $\mathrm{ml}$ blood). Cells were adjusted to $1.0 \times 10^{6} / \mathrm{ml}$ in RPMI 1640

\footnotetext{
${ }^{1}$ Abbreviations used in this paper: FCS, fetal calf serum; HBSS, Hanks' balanced salt solution; MNC, mononuclear cells; PBS, phosphate-buffered saline; PWM, pokeweed mitogen.
} 
with $10 \%$ fetal calf serum (FCS) and $0.1 \mathrm{mg} / \mathrm{ml}$ of gentamicin. $\mathrm{T}$ - and B-lymphocyte fractions were separated by density sedimentation of $E$ rosettes (13). The profile of separated lymphocytes is described below. When isolated $\mathrm{T}$ and $\mathrm{B}$ cells were prepared, glass-adherent cells were removed from MNC by incubating the cells on glass Petri dishes with $10 \%$ FCS for $40 \mathrm{~min}$ at $37^{\circ} \mathrm{C}$. The supernate containing the non-glassadherent cells was removed and washed with HBSS.

Cell surface markers. T lymphocytes were detected by Erosette formation with neuraminidase-treated sheep erythrocytes (13). B lymphocytes were detected by a combination of surface marker assays including EAC-rosette formation (14), EA-rosette formation (15), and fluorescein isothiocyanatelabeled rabbit $\mathrm{F}(\mathrm{ab})_{2}{ }^{\prime}$ anti-human $\mathrm{F}(\mathrm{ab})_{2}{ }^{\prime}$. Enriched Tlymphocyte suspensions contained $>90 \% \mathrm{E}$ rosette-forming cells and $<10 \%$ EAC rosette-forming cells, 5\% EA rosettes, and no more than $1 \%$ membrane Ig-positive cells. B lymphocyte-enriched cell suspensions contained $<10 \% \mathrm{E}$ rosetteforming cells and $>60 \%$ EAC rosettes, and $40-50 \%$ membrane Ig-positive cells. Cell viability was $>95 \%$ in all cell preparations as determined by trypan blue exclusion. Cell suspensions were incubated for $7 \mathrm{~d}$ in the presence of an optimal concentration of pokeweed mitogen (PWM, 1:200 dilution, Grand Island Biological Co., Grand Island, N. Y.). The culture medium consisted of RPMI 1640 with $10 \%$ heat-inactivated FCS and $0.1 \mathrm{mg} / \mathrm{ml}$ gentamicin. Several lots of FCS were tested for cytotoxicity, and the optimal one was used in subsequent experiments. Microculture plates (Linbro Chemical Co., Hamden, Conn.) were maintained at $37^{\circ} \mathrm{C}$ with $5 \% \mathrm{CO}_{2}$. In mixture experiments between cord and adult MNC, equal numbers of cells were mixed (a total of $3.0 \times 10^{5}$ cells) in $250 \mu \mathrm{l}$ of culture medium which contained PWM. In some experiments, cord MNC suspensions were irradiated with either 100 or 2,000 rads before mixing. In other instances $1 \mu \mathrm{M}$ of indomethacin (final concentration) (Sigma Chemical Co., St. Louis, Mo.) or $10 \mu \mathrm{M}$ of hydrocortisone succinate (Sigma Chemical Co.) was added to the culture medium. The indomethacin was added to the cultures as previously described (16). Controls for the indomethacin-addition experiments consisted of $0.01 \%$ ethanol without indomethacin. To facilitate the study of cellular interactions, enriched $\mathrm{T}$ - and $B$-cell suspensions were separated and mixed in varying ratios. B lymphocytes were adjusted to $6 \times 10^{4}$ cells per well. To this constant number of $B$ cells, varying numbers of $T$ cells were added. The total volume in each microwell was $250 \mu \mathrm{l}$. After $7 \mathrm{~d}$ plates were centrifuged $(500 \mathrm{~g}$ for $10 \mathrm{~min}$ ), and supernates were collected for radioimmunoassay measurement of Ig.

Radioimmunoassay for supernatant IgM and IgG. Flatbottom flexible microtiter plates (Cooke Lab Products Div., Dynatech Labs, Inc., Alexandria, Va.) were used for solidphase radioimmunoassays. $100 \mu$ l of purified IgG or IgM $(20 \mu \mathrm{g} / \mathrm{ml}$ in phosphate-buffered saline [PBS] that contained $0.01 \%$ sodium azide) was placed in the wells. Plates were incubated $1 \mathrm{~h}$ at $37^{\circ} \mathrm{C}$ and $16 \mathrm{~h}$ at $4^{\circ} \mathrm{C}$. Afterward, incubation wells were washed three times with PBS and dipped in gelatin buffer (PBS, $0.03 \%$ gelatin, $0.01 \%$ sodium azide). After $2 \mathrm{~h}$ at room temperature, plates were washed once with Tween-20 (Atlas Chemical Industries, Inc., Wilmington, Del.) buffer. The Tween buffer consisted of $0.05 \% \mathrm{vol} / \mathrm{vol}$ Tween in PBS which contained $0.01 \%$ sodium azide. $50 \mu \mathrm{l}$ of supernate was put in the wells, and $50 \mu \mathrm{l}$ of ${ }^{125}$ I-labeled anti-IgG or -IgM was added. Plates were incubated $30 \mathrm{~min}$ at $37^{\circ} \mathrm{C}$ and $30 \mathrm{~min}$ at $4^{\circ} \mathrm{C}$ for $\mathrm{IgG}$ or $12 \mathrm{~h}$ at $4^{\circ} \mathrm{C}$ for IgM. Wells were then washed three times with Tween buffer, and individual wells were cut out with scissors and measured in a gamma counter. The results were compared with a standard curve prepared by doubling dilutions of purified $\mathrm{Ig}(10 \mu \mathrm{g} / \mathrm{ml}$ to $10 \mathrm{ng} / \mathrm{ml})$.
Exact amounts of Ig in supernates were calculated by a computer. The computer program had two parts. First, a polynomial regression of the standard curve was established from standard dilutions, and second, each count was calculated by the polynomial regression.

Human IgG was purified from human gamma globulin Fraction II (Pentex Biochemical, Kankakee, Ill.) by DEAE chromatography. Human IgM was purified from pooled Waldenström patients' plasma with a euglobulin precipitation method and DEAE chromatography. Specificity of the antiIg antisera was verified by immunodiffusion with isolated Ig components. Rabbit anti-IgG and anti-IgM were isolated by passage of monospecific serum through appropriate immunoabsorption columns and elution of specific antibody before labeling. The purified monospecific anti-Ig were radiolabeled with ${ }^{125}$ I by the chloramine-T method (17).

\section{RESULTS}

Initially, experiments were performed to measure IgG and IgM production of adult MNC vs. cord MNC and in mixtures of the two. Normal adult MNC produced $4,005 \pm 596($ mean \pm SE) $\mathrm{ng} / \mathrm{ml}$ of IgG and $2,497 \pm 489$ $\mathrm{ng} / \mathrm{ml}$ of IgM. Cord MNC produced only $105 \pm 40 \mathrm{ng} / \mathrm{ml}$ of IgG and $37 \pm 12 \mathrm{ng} / \mathrm{ml}$ of IgM. In nine mixture experiments between adult and cord MNC, adult Ig production was remarkably diminished $(P<0.005$ for IgG and $P<0.0025$ for IgM). The predicted amount is indicated by the dark bars in Fig. 1. Predicted values were calculated with the following formula: Adult Ig production + cord Ig production $/ 2=$ predicted $\mathrm{Ig}$ production.

A significant suppression of $\mathrm{Ig}$ production was not observed in 20 mixture experiments with allogeneic

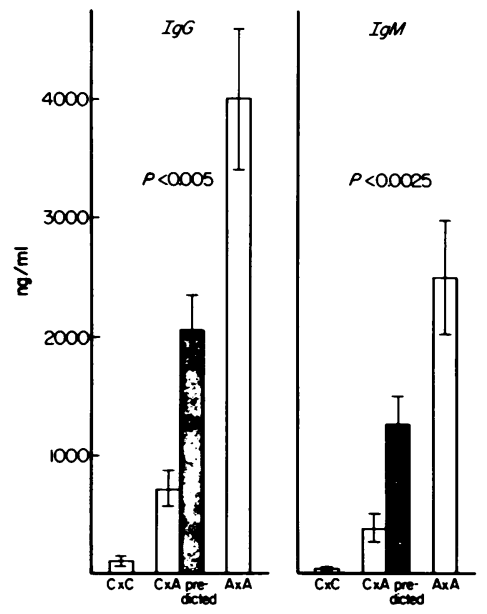

FigURE 1 Ig production by PWM-stimulated human adult and cord blood cells. $\mathrm{C} \times \mathrm{C}=\mathrm{Ig}$ production by $3.0 \times 10^{5}$ cord MNC expressed as nanograms per milliliter (mean \pm SE) of IgG or IgM in $0.25 \mathrm{ml}$ of culture medium (nine experiments), $\mathrm{A} \times \mathrm{A}=\mathrm{Ig}$ production by $3 \times 10^{5}$ adult $\mathrm{MNC}$ (nine experiments), $\mathbf{A} \times \mathbf{C}=\mathrm{Ig}$ production by an equal mixture of cord blood $\left(1.5 \times 10^{5}\right)$ and adult MNC $\left(1.5 \times 10^{5}\right)$ (nine experiments). The predicted production (dark bar) of $\mathrm{C} \times \mathrm{A}$ was calculated as described in Results. 
TABLE I

Effect on Ig Production Resulting from the Mixture of Adult Allogeneic Cells

\begin{tabular}{clc}
\hline Cell type & \multicolumn{1}{c}{ IgG } & IgM \\
\hline \multicolumn{3}{c}{$n g / m l$} \\
$\mathrm{~A}_{1} \times \mathrm{A}_{1}{ }^{*}(1: 1)$ & $2,002.7 \pm 298.1 \pm$ & $1,248.5 \pm 244.5 \neq$ \\
$\mathrm{A}_{1} \times \mathrm{A}_{2}{ }^{*}(1: 1)$ & $1,529.7 \pm 222.8$ & $1,347.1 \pm 381.2$ \\
$\mathrm{~B}_{1} \times \mathrm{T}_{1}^{*}(1: 1)$ & $1,312.4 \pm 258.4$ & $1,008.5 \pm 267.1$ \\
$\mathrm{~B}_{1} \times \mathrm{T}_{2}{ }^{*}(1: 1)$ & $1,315.9 \pm 531.6$ & $1,007.9 \pm 282.8$ \\
\hline
\end{tabular}

There was no statistical difference between Ig production of $A_{1} \times A_{1}$ and $A_{1} \times A_{2}(0.10<P<0.15$ for IgG, $0.40<P<0.45$ for $\operatorname{IgM})$. Likewise there was no significant difference between $B_{1} \times T_{1}$ and $B_{1} \times T_{2}(0.495<P<0.497$ for IgG, $0.497<P<0.499$ for IgM).

$* A_{1} \times A_{1}=$ Syngeneic cell culture; $A_{1} \times A_{2}=$ allogeneic culture between two different adults cells; $B_{1} \times T_{1}=$ syngeneic culture between autologous $\mathrm{B}$ and $\mathrm{T}$ cells; $\mathrm{B}_{1} \times \mathrm{T}_{2}=$ allogeneic culture between purified $\mathrm{B}$ and $\mathrm{T}$ cells derived from two different adults.

$\$$ Ig produced by $1.5 \times 10^{5}$ cells in $0.25 \mathrm{ml}$ of culture medium (mean $\pm \mathrm{SE}$ ).

adult MNC. As seen in Table I, the Ig production from syngeneic cultures of normal adult cells $\left(A_{1} \times A_{1}\right)$ was not significantly different from allogeneic cultures of normal adult cells $\left(\mathrm{A}_{1} \times \mathrm{A}_{2}\right)(0.10<P<0.15$ for $\mathrm{IgG}$, $0.40<P<0.45$ for $\operatorname{IgM})$. Likewise, there were no significant differences between allogeneic vs. syngeneic cultures of B and T cells (Table I).

When normal adult B lymphocytes were cultured with PWM without T lymphocytes, Ig production was impaired. To examine the influence of $T$ lymphocytes on Ig production by B lymphocytes, T and B lymphocytes were separated and cocultured in varying ratios (Figs. 2 and 3). When varying ratios of adult $\mathrm{T}$ cells were added to a constant number of adult $B$ lymphocytes, B lymphocytes were stimulated to produce IgG and IgM. However, if cord T lymphocytes were added to adult $\mathrm{B}$ lymphocytes, cord $\mathrm{T}$ lymphocytes suppressed or did not help Ig production of adult B lymphocytes. In Fig. 2 it can be seen that the addition of cord $T$ cells to adult $B$ cells caused a significant inhibition of IgM production $(P<0.05)$. A similar suppressive effect was noted with IgG (Fig. 3) $(P<0.05)$. Cord T lymphocytes did not help cord B lymphocytes to produce Ig. Moreover, if adult T lymphocytes were added to cord B lymphocytes, cord B lymphocytes did not respond with increased supernatant Ig production. These data are shown in Figs. 2 and 3.

To determine if the lowered Ig production noted in adult and cord MNC cocultures was modified by glucocorticoids, indomethacin, or $x$ ray, the Ig production in mixed-cell suspensions was measured after the addition of these drugs to the culture medium or after

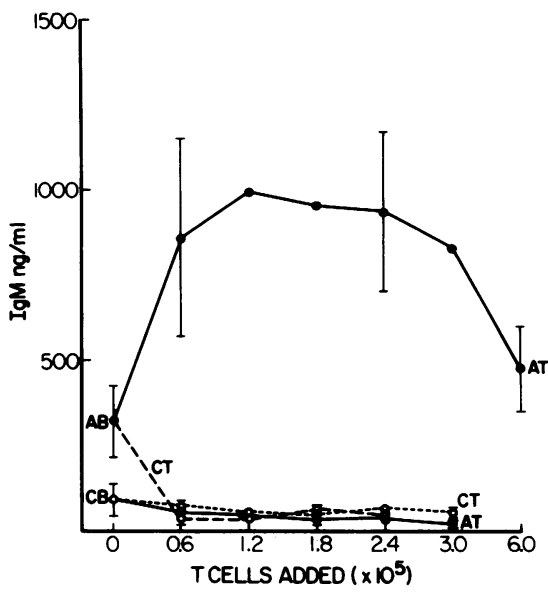

Figure 2 The effect on IgM production resulting from the addition of $\mathrm{T}$ cells to enriched $\mathrm{B}$-cell suspensions. $\mathrm{AB}=$ adult $\mathrm{B}$ cells, $\mathrm{AT}=$ adult $\mathrm{T}$ cells, $\mathrm{CB}=$ cord $\mathrm{B}$ cells, and $\mathrm{CT}=$ cord $\mathrm{T}$ cells. $6 \times 10^{4} \mathrm{~B}$ cells were present in each well to which varying numbers of $\mathrm{T}$ cells were added. Results are expressed as the mean $\pm \mathrm{SE}$ of five different experiments.

irradiation of cord cells. Results of these experiments are shown in Fig. 4. In the presence of indomethacin $(1 \mu \mathrm{M})$, there was no significant change in Ig production. Likewise, when the cord MNC were irradiated with 100 rads before mixing them with adult MNC, there was no significant change in Ig production. However, if purified cord $T$ cells were irradiated with 2,000 rads before addition to unfractionated adult $\mathrm{MNC}$, the suppressive effect of the cord cells was abrogated and Ig production increased to normal levels. These data are shown in Fig. 5.

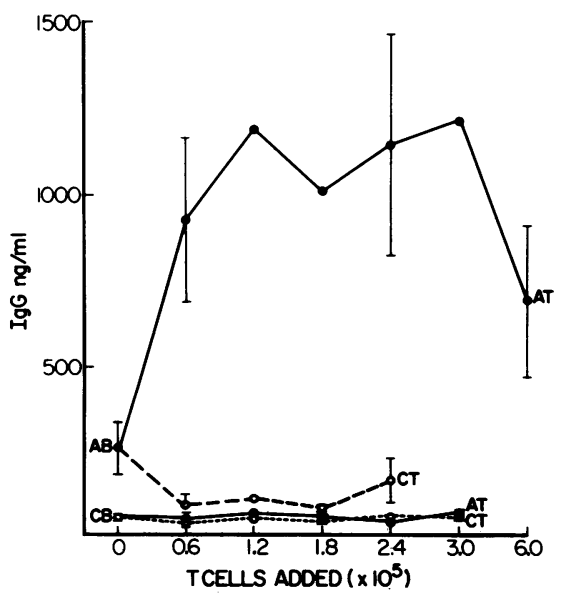

Figure 3 The effect on IgG production resulting from the addition of $T$ cells to enriched $B$-cell suspensions. AB $=$ adult $\mathrm{B}$ cells, $\mathrm{AT}=$ adult $\mathrm{T}$ cells, $\mathrm{CB}=$ cord $\mathrm{B}$ cells, and $\mathrm{CT}=$ cord $\mathrm{T}$ cells. $6 \times 10^{4} \mathrm{~B}$ cells were present in each well to which varying numbers of $T$ cells were added. Results are expressed as the mean $\pm \mathrm{SE}$ of five different experiments. 

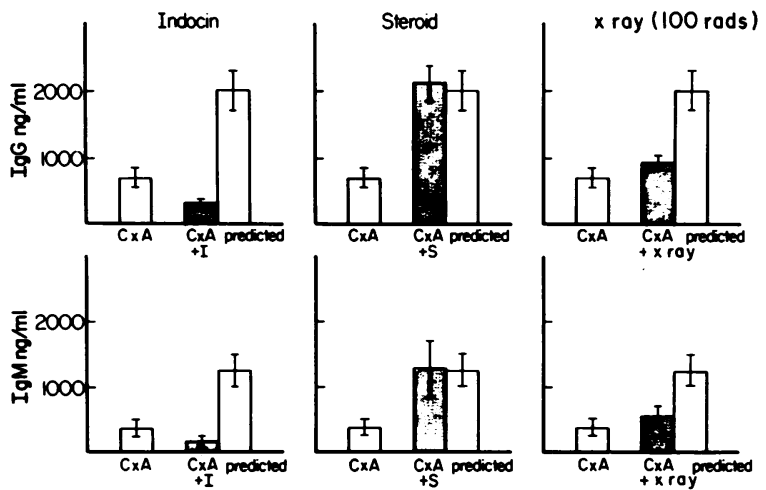

Figure 4 The effect of drugs and low dose $x$ ray on the Ig production by mixtures of cord blood and adult mononuclear cells. $\mathrm{C} \times \mathrm{A}=\mathrm{Ig}$ production by an equal number of cocultured cord blood $\left(1.5 \times 10^{5}\right)$ and adult MNC $\left(1.5 \times 10^{5}\right)$. Results (dark bar) are expressed as the mean $\pm S E$ in nanograms per milliliter supernate (four experiments). The predicted synthesis was calculated as described in Results. $I=$ indomethacin $(1 \mu \mathrm{M}), \mathrm{S}=$ hydrocortisone succinate $(10 \mu \mathrm{M}), \mathrm{x}$ ray means that the cord blood cells were irradiated with 100 rads before coculture with unirradiated adult cells.

Finally, when hydrocortisone succinate $(10 \mu \mathrm{M})$ was added to mixtures of adult and cord MNC (Fig. 4), the amounts of IgG and IgM produced were not decreased, but rose to within the predicted range. Restoration of Ig production in the latter cord-adult cell mixed cultures was further explored with brief, 3-h preincubation of either adult or cord MNC with the same concentration of hydrocortisone succinate followed by washing three times with HBSS. These experiments did not result in IgG or IgM production within the predicted range, which indicates that continuous or more prolonged presence of corticosteroid was necessary for restoration of expected Ig production.

\section{DISCUSSION}

The addition of cord MNC to adult MNC leads to an impairment of predicted IgG and IgM production. The results obtained with enriched $B$ and $T$ cells did not differentiate initially between the possibility that cord $T$ lymphocytes have an increased suppressor effect or a deficient helper influence. However, the mixture experiments with unfractionated $\mathrm{MNC}$ were consistent with the possibility that the impaired Ig production observed when cord and adult MNC were cocultured might be a result of the presence of a cord suppressorcell subpopulation. In addition, it was clear from the data presented here that cord B lymphocytes cannot respond normally to adult $\mathrm{T}$ helper-cell populations. The lack of Ig production by cord B cells in the presence of allogeneic adult helper $\mathrm{T}$ cells may have been a result of the fact that exact histocompatability matching between interacting cells is necessary for effective help to occur. However, this seems unlikely because allogeneic combinations between adult $\mathrm{T}$ and $\mathrm{B}$ cells resulted in effective Ig production and no relative diminution in Ig synthesis (Table I). Autologous cord $\mathrm{T}$ cells showed no effective cellular interaction with cord B cells and no detectable increment in Ig production. These findings support the experiments of Yata et al. (18), who found that in most
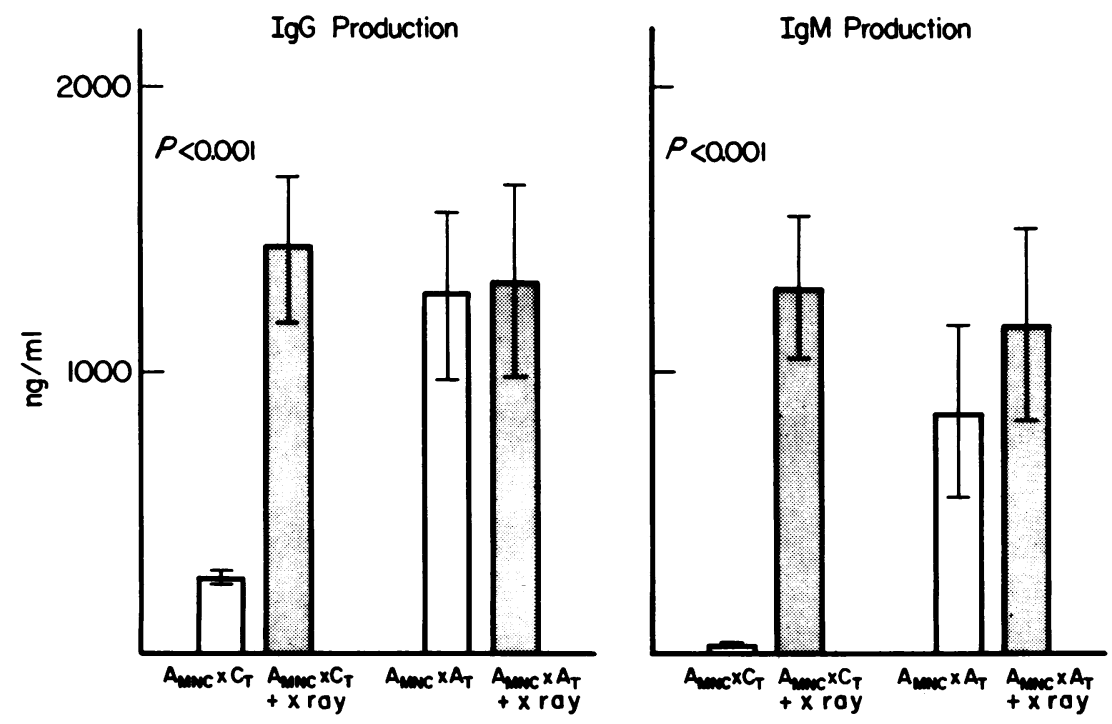

Figure 5 The sensitivity of cord suppressor T cells to 2,000-rad dose of $x$ ray. Purified cord or adult $\mathrm{T}$ cells were added to unfractionated adult $\mathrm{MNC}$ (1:1.6). $\mathrm{A}=$ adult, $\mathrm{C}=$ cord. The cord or adult $T$ cells were irradiated with 2,000 rads (experiments shown as dark bars) before addition to unirradiated adult cells. 
instances, strict requirement of histocompatability matching between human $\mathrm{T}$ and $\mathrm{B}$ cells in mitogeninduced in vitro Ig production was not necessary.

Our results support the findings of Oldstone et al. (11), who showed that newborn $T$ cells suppressed the production of IgG by maternal B cells. In addition, these workers showed that cord blood T-lymphocytes bearing $\mathrm{Fc}_{\mathrm{c}}$ receptors for IgG effectively suppressed maternal lymphocyte proliferation and are effective in reducing maternal B-cell production of IgG. However, another recent report by Hayward and Lydyard (19) suggested that a cord $\mathrm{T}$ cell with an $\mathrm{Fc}$ receptor for $\mathrm{IgM}$ as well as cells with an IgG-Fc receptor suppressed B-lymphocyte differentiation.

With these data in mind, the striking changes recorded after in vitro treatment of cells with corticosteroids are of considerable interest. Addition of steroids to the cultures enhanced IgG and IgM production to the predicted levels in coculture experiments involving cord and adult MNC. These findings may relate to stimulation of $\mathrm{B}$ cells, obliteration of putative suppressor cells, or to enhancement of helper $\mathrm{T}$ effects by corticosteroid action. Our results are similar to those of Fauci et al. (20), who attributed enhanced plaque-forming cell responses in the presence of hydrocortisone to modulation of the triggering signal either directly on B cells or through changes in balance of T-cell regulation of B-cell response. Furthermore, data obtained with short-term 3-h preincubation with corticosteroid followed by washing indicate that steroid may be necessary through coculture to restore normal Ig synthesis.

In contrast to results noted after in vitro corticosteroid addition, no significant effects were recorded when in vitro indomethacin was added to cord and adult cells in cocultures. This would indicate that prostaglandin-producing suppressor cells (16) are probably not a significant governing factor in basic control of Ig synthesis under such circumstances.

Finally, the relative increment in Ig production after 2,000 rads irradiation of cord $T$ cells then cocultured with adult MNC provides direct evidence for radiationsensitive cord T-suppressor cells. Such suppressor cells sensitive to irradiation have been previously described in adult patients with hypogammaglobulinemia (21). The cord suppressor $\mathrm{T}$ cell, however, was not affected by low-dose (100 rads) irradiation.

These studies provide initial base-line data which may eventually be of use in dissecting out the precise mechanisms of immunological immaturity long recognized to be intrinsic to the human newborn state.

\section{ACKNOWLEDGMENTS}

This study was supported by U. S. Public Health Service grants AI 13824-10, AI 13433-02, CA 27873, and 13690-09; and in part by a grant from the American Cancer Society.

\section{REFERENCES}

1. Medawar, P. B. 1954. Some immunological and endocrinological problems raised by the evolution of viviparity in vertebrates. Symp. Soc. Exp. Biol. 7: 320-328.

2. Beer, A. E., and R. E. Billingham. 1975. Immunologic coexistence in the maternal-fetal relationship. In Modern Perinatal Medicine. L. Gluck, editor. Year Book Medical Publishers, Inc. Chicago, Ill. 83-89.

3. Buckley, R. H., R. I. Schiff, and D. B. Amos. 1972. Blocking of autologous and homologous leukocyte responses by human alloimmune plasmas: a possible in vitro correlate of enhancement. J. Immunol. 108: 34-44.

4. Kasakura, S. 1971. A factor in maternal plasma during pregnancy that suppresses the reactivity of mixed leukocyte cultures. J. Immunol. 107: 1296-1301.

5. Harrison, M. R. 1976. Maternal immunocompetence II. Proliferation responses of maternal lymphocytes in vitro and inhibition by serum from pregnant rats. Scand. J. Immunol. 5: 881-889.

6. Rocklin, R. E., J. L. Kitzmiller, C. B Carpenter, M. R. Garovoy, and J. R. David. 1976. Maternal-fetal relation. Absence of an immunologic blocking factor from the serum of women with chronic abortions. N. Engl. J. Med. 295: 1209-1213.

7. Rocklin, R. E., J. E. Zuckerman, E. Alpert, and J. R. David. 1973. Effect of multiparity on human maternal hypersensitivity to fetal antigen. Nature (Lond.). 241: 130-131.

8. Lawler, S. D., E. O. Ukaejiofo, and B. R. Reeves. 1975. Interaction of maternal and neonatal cells in mixedlymphocyte cultures. Lancet. II: 1185-1187.

9. Olding, L. C., K. Bernischke, and M. B. A. Oldstone 1974. Inhibition of mitosis of lymphocytes from human adults by lymphocytes from human newborns. Clin. Immunol. Immunopathol. 3: 79-89.

10. Olding, L. C., and M. B. A. Oldstone. 1976. Thymusderived peripheral lymphocytes from human newborns inhibit division of their mother's lymphocytes. J. Immunol. 116: 682-686.

11. Oldstone, M. B. A., A. Tishon, and L. Moretta. 1977. Active thymus derived suppressor lymphocytes in human cord blood. Nature (Lond.). 269: 333-335.

12. Bøyum, A. 1968. Isolation of mononuclear cells and granulocytes from human blood. Scand. J. Clin. Lab. Invest. 21 (Suppl. 97): 77-90.

13. Galili, U., and M. Schlesinger. 1974. The formation of stable E rosettes after neuraminidase treatment of either human peripheral blood lymphocytes or of sheep red blood cells. J. Immunol. 112: 1628-1634.

14. Nakai, H., T. Morito, K. Tanimoto, and Y. Horiuchi. 1977. Reduced Fc-receptor bearing cells in the peripheral blood of patients with systemic lupus erythematosus and in rheumatoid synovial fluids. J. Rheumatol. 4: 405-413.

15. Bankhurst, A. D., E. Hastain, G. Husby, E. DiazJouanen, and R. C. Williams, Jr. 1978. Human lymphocyte subpopulations defined by double surface markers. $J$. Lab. Clin. Med. 91: 15-23.

16. Goodwin, J. S., A. D. Bankhurst, and R. P. Messner 1977. Suppression of human T-cell mitogenesis by prostaglandin: existence of a prostaglandin producing suppressor cell. J. Exp. Med. 146: 1719-1734.

17. Klinman, N., and R. Taylor. 1969. General methods for the study of cells and serum during the immune response: the response to dinitrophenyl in mice. Clin. Exp. Immunol. 4: 473-487.

18. Yata, J., N. Kobayashi, T. Shimbo, U. Kakihara, M. Sugahara, and T. Yamakura. 1978. Requirement of HLA 
compatibility between $\mathrm{T}$ - and B-cells in mitogen-induced in vitro immunoglobulin production. J. Clin. Lab. Immunol. 1: 245-248.

19. Hayward, A. R., and P. M. Lydyard. 1978. Suppressor of B lymphocyte differentiation by newborn $\mathrm{T}$ lymphocytes with an Fc receptor for IgM. Clin. Exp. Immunol. 34: 374-378.

20. Fauci, A. S., K. R. Pratt, and G. Whalen. 1977. Activation of human B lymphocytes. IV. Regulatory effects of corticosteroids on the triggering signal in the plaqueforming cell response of human peripheral blood B lymphocytes to polyclonal activation. J. Immunol. 119: 598-603.

21. Siegal, F. P., M. Siegal, and R. A. Good. 1978. Role of helper, suppressor and B-cell defects in the pathogenesis of the hypogammaglobulinemias. N. Engl. J. Med. 299: $172-178$. 